\title{
Research of Stability of "Exkair" Tablets by the Method of Long-Term Storage
}

\section{Urziya Alimova, Assyl Boshkayeva, Nurgan Tussupova, Roza Omarova, Galiya Ibadullayeva, Zuriyadda Sakipova, Yernar Dzhadranov, Kurakbai Zharimbetov, Eduard Bissenbaev, Ubaidulla Datkhayev}

Asfendiyarov Kazakh National Medical University, Almaty, Republic of Kazakhstan

\section{Email address:}

earth_u.a@@mail.ru (U. Alimova), kenes65@mail.ru (A. Boshkayeva), tusupova-n@mail.ru (N. Tussupova), rozochka_omarova@mail.ru (R. Omarova), arujan-d@mail.ru (G. Ibadullayeva), sakipova@archipelag.kz (Z. Sakipova), y.dzhadranov@mail.ru (Y. Dzhadranov),k.zharimbetov@mail.ru (K. Zharimbetov), bissenbayev1941@mail.ru (E. Bissenbaev), u.datxaev@mail.ru (U. Datkhayev)

\section{To cite this article:}

Urziya Alimova, Assyl Boshkayeva, Nurgan Tussupova, Roza Omarova, Galiya Ibadullayeva, Zuriyadda Sakipova, Yernar Dzhadranov, Kurakbai Zharimbetov, Eduard Bissenbaev, Ubaidulla Datkhayev. Research of Stability of "Exkair" Tablets by the Method of Long-Term Storage. Clinical Medicine Research. Vol. 5, No. 2, 2016, pp. 13-19. doi: 10.11648/j.cmr.20160502.12

Received: February 16, 2016; Accepted: April 13, 2016; Published: April 26, 2016

\begin{abstract}
The raised standard requirements regulated by the State Pharmacopoeia and the Analytical Normative Document (AND) are imposed to quality of the medicines applied in medical practice of the Republic of Kazakhstan. One of the main requirements imposed to quality of medicines is stability. The specification of test of stability of the tablets "Exkair" reflecting an assessment of physical and chemical properties of tablets and the list of indicators of quality according to requirements of the project of the AND is developed for expression of this concept. Determination of stability of tablets was carried out in the mode (long-term/real time testing) of long-term tests: temperature of natural storage $-25 \pm 2{ }^{\circ} \mathrm{C}$, relative humidity $-(60 \pm 5) \%$. The indicators of quality of tablets included in the specification of stability on HP "Exkair" with reduction of test conditions and techniques of definition are presented. Results of test of stability of tablets confirm structure of a preparation: active substances - extract from the rhizomes of Acorus Calamus $(0.009 \mathrm{~g})$, extract of flowers of the Calendula officinalis $(0.003 \mathrm{~g})$; auxiliary substances - ascorbic acid $(0.005 \mathrm{~g})$, calcium stearate $(0.006 \mathrm{~g})$, sugar powder $(0.517 \mathrm{~g})$, aerosil $(0.0015 \mathrm{~g})$. On the basis of these test the assessment of quality of tablets with establishment of numerical values of parameters including period of storage is carried out. Period of storage of medicine established experimentally by the method of long-term storage under natural conditions within 2 years in packing regulated by the draft of the Analytical Normative Document (AND). Initial period of storage of the tablets "Exkair" makes 2 years. In this research period of storage of ready medicine was determined irrespective of expiration dates of the main substance (extract from the rhizomes of Acorus Calamus and extract of flowers of the Calendula officinalis).
\end{abstract}

Keywords: Extracts, Tablets, Stability, Quality of Drugs, Storage, Provisional Analytical Normative Document (PAND)

\section{Introduction}

Determination of the stability and shelf life, is an important requirement for new drugs $[1,2,3,4]$. As is known, the conditions of storage of medicinal products should ensure the preservation of property, safety of medicines throughout their life-cycle, to prevent contamination, cross-contamination and regrading.

Stability of the medicinal substances (MS) and their quality are inseparably linked among themselves. Experts of various field of pharmacy, including pharmaceutical chemistry are engaged in the solution of this problem. Important criterion of stability is preservation of quality of medicinal substances. Decrease in quantitative content pharmacological of active agent in the medicines confirms instability. Reduction of amount of (MS) shouldn't be followed by formation of toxic products or change of physical and chemical properties of the operating 
components and decrease them for $10 \%$ shouldn't happen within 3-4 years in ready dosage forms $[5,6,7,8]$.

As period of storage of medicines understand the period of time during which they have to keep completely the therapeutic activity, harmlessness and on the level of qualitative and quantitative characteristics to conform to requirements of the State Pharmacopoeia and the provided on this dosage form that is AND $[9,10]$. After an expiration date vedicine can't be used without the corresponding requality control.

Decomposition at the wrong storage of medicines can be established on appearance. However formation of products of decomposition isn't always followed by noticeable decrease in pharmacological activity of medicines. Not always external changes can be caused by decomposition of insignificant amount of medicinal substances with formation of nontoxical or indifferent products of decomposition. AND allows a certain amount of such impurity in medicinal substances. Sometimes external doesn't undergo changes of medicines, however at their chemical research the impurity of products of decomposition differing in toxicity or other orientation of pharmacological action are found. Control of availability of such impurity is strictly regulated by AND.

Pay to questions of stability of medicines huge attention, however approach to this problem was purely empirical. The assessment of quality was carried out on change of taste, color, a consistence, formation of a deposit and so on. Only in the last decades research of stability is put on a scientific basis.

Increase of stability of the medicines can be reached on the basis of research of indicators of quality of the medicines defining their period of storage. Test of stability of medicines is the obligatory module of the registration file $[11,12]$.

Research objective was research of stability of the tablets "Exkair" by method of long-term storage under natural conditions.

Research problems:

- To develop the specification of long-term test of stability of the tablets "Exkair" on quality indicators according to the draft of AND;

- To develop techniques of definition of indicators of quality of tablets;
- To establish numerical values of parameters of quality of the tablets "Exkair";

- To determine period of storage of the tablets "Exkair".

\section{Results and Discussion}

By using the classical method of determining the stability of the (long-term) drug in the expiration date is stored in compliance with the required conditions and analyzed by PAND (Provisional Analytical Normative Document). Then give a conclusion about the optimal shelf life.

"Exkair" studies conducted on stability of tablets three experimental-industrial batches produced in the laboratory of the Partnership, Limited Liability Partnership (LLP) "Production of medicines "ZHANAFARM". Tests were conducted in the package for sale (contour special packaging made of paper with polyethylene according to TS (technical specifications) 9572-037-11624078-99). Terms and regulations of the frequency of the tests: $0,3,6,9,12,18,24$ months, the storage temperature of $25 \pm 2^{\circ} \mathrm{C}$, relative humidity $(60 \pm 5) \%$.

In line with the specification of the results of the definition of stability, covering a set of indicators obtained by physical, chemical and microbiological tests.

Over 2 years does not change the composition of the tablets in the primary package. Qualitative and quantitative characteristics of quality parameters were within acceptable limits.

Primary packaging provides adequate protection of the drug against external influences, microbiological characteristics were unchanged and in full compliance with the requirements of the specification.

The results of stability studies indicate the ethnic composition of the drug, the optimum technology for tablets "Exkair" three series (Table 1). Composition "Exkair" pill: active substance - thick extract of rhizome Acorus Calamus $(0.009 \mathrm{~g})$ and dense extract of flower Calendula officinalis (0.003); auxiliary substances - ascorbic acid (0.005 g), calcium stearate $(0.006 \mathrm{~g})$, sugar powder $(0.517 \mathrm{~g})$, aerosil $(0.0015 \mathrm{~g})$. Excipients are selected in accordance with the technological purpose, with the physico-chemical and functional characteristics.

Table 1. Experimental industrial series of Exkair'tablets for the research of stability.

\begin{tabular}{llll}
\hline № series & Mass of series & Date of manufacture & \multicolumn{1}{c}{ Time of research (months) } \\
\hline 100313 & $49.9 \mathrm{~kg}$ & the fifth of March 2013 & $0,3,6,9,12,18,24$. \\
100314 & $50.0 \mathrm{~kg}$ & the tenth of March 2013 & $0,3,6,9,12,18,24$. \\
100315 & $51.9 \mathrm{~kg}$ & the fifteenth of March 2013 & $0,3,6,9,12,18,24$. \\
\hline
\end{tabular}

Table 2-4 shows the results of determining the stability embracing complex of quality parameters of tablets "Exkair", obtained by physical, chemical and microbiological tests: description, identification, average mass, the deviation from the average mass, content uniformity, abrasion strength disintegration, aerosil, related impurities, microbiological purity, quantify the content of active substance (camphor, $\beta$ pinene, based on the carotenoid $\beta$-carotene). The norms of deviations and test methods for these quality parameters are in accordance with draft of PAND [14]. In tabular data are given the description of all indicators of quality of the tablets "Exkair".

Related impurity.

Determination of related impurities was performed by gas chromatography (State Pharmacopoeia of Republic of Kazakhstan I, vol. 1, 2.2.28) [15].

$5330.0 \mathrm{mg}$ weighed sample is placed in a volumetric flask of $100 \mathrm{ml}, 60 \mathrm{ml}$ of water is added P, stirred until dissolved, bring 
to the mark with the same solvent and stirred (test solution).

Weigh $20.0 \mathrm{mg}$ of 5-hydroxymethylfurfural (SigmaAldrich, № W501808 category or equivalent quality) was placed in a volumetric $200 \mathrm{~mL}$ flask, dissolved in $50 \mathrm{ml}$ of water, $\mathrm{P}$, the solution was stirred and brought up to the mark with the same solvent. $5.0 \mathrm{ml}$ of this solution was placed in a volumetric flask of $100 \mathrm{ml}$, the solution volume is adjusted to the mark with water and mix P.

1 microliter $(\mathrm{mcl})$ test solution and reference solution was chromatographed successively on a gas chromatograph with a flame ionization detector to obtain at least 5 chromatograms, the following conditions:

- column capillary quartz the size of $30 \mathrm{~m} \mathrm{x} 0.32 \mathrm{~mm}$ coated with a stationary phase layer - poly [(cyanopropyl) (phenyl)] [dimethyl] siloxane, thickness $1.8 \mathrm{~mm}$, or equivalent, which satisfies the requirements of the test "Check the suitability of the chromatographic system";

- column oven temperature was programmed from $40^{\circ} \mathrm{C}$ (delayed 12 minutes) to $240^{\circ} \mathrm{C}$ (delay of 8 minutes), the rate of increase of temperature $-10^{\circ} \mathrm{C} / \mathrm{min}$;

- the temperature of the evaporator unit $-200^{\circ} \mathrm{C}$;

- flow separation - 1:20;

- detector temperature $-280^{\circ} \mathrm{C}$;

- the flow rate of carrier gas (helium for chromatography $\mathrm{R})-35 \mathrm{~cm} / \mathrm{sec}$;

- injection volume - $1 \mathrm{mcl}$.

Area 5-hydroxymethylfurfural peak in the chromatogram of the test solution should not exceed the peak area in the chromatogram of the reference solution $(0.1 \%)$.

The peak area of any unidentified impurities on the chromatogram of the test solution should not exceed the peak area of the 5-hydroxymethylfurfural in the chromatogram of the reference solution $(0.1 \%)$.

The sum of the peak areas of impurities should not exceed five areas of 5-hydroxymethylfurfural peak in the chromatogram of the reference solution $(0.5 \%)$.

Do not take into account the system peak and placebo peaks.

The results are considered reliable if the requirements of the test, "Check the suitability of the chromatographic system".
Notes. Preparation of the reference solution. Weigh 20.0 $\mathrm{mg}$ of 5-hydroxymethylfurfural (Sigma-Aldrich, Cat. № W501808 quality or similar) was placed in a volumetric 200 $\mathrm{mL}$ flask, dissolved in $50 \mathrm{ml}$ of water $\mathrm{P}$, the solution was stirred and brought up to the mark with the same solvent. 5.0 $\mathrm{ml}$ of this solution was placed in a volumetric flask of 100 $\mathrm{ml}$, the solution volume is adjusted to the mark with water $\mathrm{P}$ and mix.

Check the suitability of the chromatographic system. The chromatographic system is considered suitable when the condition: the symmetry factor of the peak 5hydroxymethylfurfural should be between 0.8 to 1.5 ;

- the relative standard deviation of repeated administration should not exceed $2.0 \%$.

Microbiological purity.

Test to determine the microbiological purity is carried out in accordance with the requirements of State Pharmacopoeia of Republic of Kazakhstan, 2.6.12, 2.6.13, category 3 A.

Preparation of test solution. $10 \mathrm{~g}$ of crushed tablets average sample is placed in a sterile graduated vessel, the volume was adjusted to $100 \mathrm{ml}$ sterile phosphate buffer solution and sodium chloride peptone $\mathrm{pH} 7.0$ and mixed.

Determination of total bacterial count. In $1.0 \mathrm{ml}$ of the test sample are plated two-layer method on each of two Petri dishes with nutrient dense number 1 .

Determination of the total number of fungi. $1.0 \mathrm{ml}$ of the test sample by two-layer plated on each of two Petri dishes with nutrient dense № 2 .

Testing for the presence of bacteria of the family Enterobacteriaceae. $10.0 \mathrm{ml}$ of test sample introduced into $100 \mathrm{ml}$ of medium № 3 .

Testing for the presence of Staphylococcus aureus and Pseudomonas aeruginosa. $10.0 \mathrm{ml}$ of test sample introduced into $100 \mathrm{ml}$ of medium № 8 .

The preparation is allowed total viable aerobic microorganisms is not more than $10^{3}$ bacteria and fungi not more than $10^{2}$ in $1 \mathrm{~g}$.

It is not allowed the presence of Enterobacteriaceae in $1 \mathrm{~g}$.

It is not allowed the presence of Staphylococcus aureus and Pseudomonas aeruginosa in $1 \mathrm{~g}$.

Table 2. Results of research of stability of Exkair'tablets (series 100313).

\begin{tabular}{|c|c|c|c|c|}
\hline \multicolumn{5}{|c|}{ Temperature: $25 \pm 2^{\circ} \mathrm{C}$ Date of the beginning of research - 10.03.2013 } \\
\hline \multicolumn{5}{|c|}{ Relative humidity: $60 \pm 5 \%$ Date of the finishing of research - 10.03.2015 } \\
\hline \multicolumn{5}{|c|}{ Packing - contour non-porous } \\
\hline & & Months & & \\
\hline & & 1 & 3 & 6 \\
\hline Description & $\begin{array}{l}\text { Tablets are cream-coloured, } \\
\text { flattened cylindrical in shape. }\end{array}$ & $\begin{array}{l}\text { normal in accordance with } \\
\text { PAND Tablets from } \\
\text { rhizome Acorus Calamus } \\
\text { and from flower Calendula } \\
\text { officinalis }\end{array}$ & $\begin{array}{l}\text { normal in accordance with } \\
\text { PAND Tablets from rhizome } \\
\text { Acorus Calamus and from } \\
\text { flower Calendula officinalis }\end{array}$ & $\begin{array}{l}\text { normal in accordance with } \\
\text { PAND Tablets from } \\
\text { rhizome Acorus Calamus } \\
\text { and from flower Calendula } \\
\text { officinalis }\end{array}$ \\
\hline Identification & $\begin{array}{l}\text { In the chromatogram of the } \\
\text { experimental solution the time of } \\
\text { principal peak should coincide } \\
\text { with the time of camphor peak in } \\
\text { the chromatogram of comparative } \\
\text { solution. }\end{array}$ & $\begin{array}{l}\text { normal in accordance with } \\
\text { PAND }\end{array}$ & $\begin{array}{l}\text { normal in accordance with } \\
\text { PAND }\end{array}$ & $\begin{array}{l}\text { normal in accordance with } \\
\text { PAND }\end{array}$ \\
\hline Average mass & Average mass of tablets $0.580 \mathrm{~g}-$ & 0.59 & 0.60 & 0.60 \\
\hline
\end{tabular}




\begin{tabular}{|c|c|c|c|c|}
\hline \multicolumn{5}{|c|}{$\begin{array}{l}\text { Temperature: } 25 \pm 2^{\circ} \mathrm{C} \text { Date of the beginning of research }-10.03 .2013 \\
\text { Relative humidity: } 60 \pm 5 \% \text { Date of the finishing of research }-10.03 .2015\end{array}$} \\
\hline \multicolumn{5}{|c|}{ Packing - contour non-porous } \\
\hline & & Months & & \\
\hline & & 1 & 3 & 6 \\
\hline Disintegration, min & $\begin{array}{l}0.629 \mathrm{~g} . \\
\text { Not more than fifteen minutes in } \\
\text { water (min). }\end{array}$ & 9 & 8 & 7 \\
\hline Abrasion strength & Not more than $1 \%$ (in per cent). & 0.4 & 0.5 & 0.4 \\
\hline $\begin{array}{l}\text { Firmness (in case of } \\
\text { crushin) }\end{array}$ & Not less than $3.5 \mathrm{H}$. & 3.8 & 3.9 & 4.1 \\
\hline Aerosil & Not more than $5.5 \%$. & 2.4 & 2.3 & 2.4 \\
\hline $\begin{array}{l}\text { Related impurities: 5- } \\
\text { hydroxymethylfurfural }\end{array}$ & Not more than $0.1 \%$. & 0.05 & 0.07 & 0.05 \\
\hline Microbiological purity & $\begin{array}{l}\text { One gramm of the drug should } \\
\text { contain not more than } 10^{3} \\
\text { bacteria, } 10^{2} \text { yeast and mycelia } \\
\text { fungi. The drug shouldn't contain } \\
\text { Escherichia coli. }\end{array}$ & $\begin{array}{l}\text { normal in accordance with } \\
\text { requirements of the project } \\
\text { PAND }\end{array}$ & $\begin{array}{l}\text { normal in accordance with } \\
\text { requirements of the project } \\
\text { PAND }\end{array}$ & $\begin{array}{l}\text { normal in accordance with } \\
\text { requirements of the project } \\
\text { PAND }\end{array}$ \\
\hline Content of: - camphor & Not less than $0.9 \mathrm{mg}$ in a tablet. & 0.91 & 0.82 & 0.91 \\
\hline - $\beta$-pinen & Not less than $0.9 \mathrm{mg}$ in a tablet. & 0.90 & 0.87 & 0.86 \\
\hline
\end{tabular}

Table 2. Continue.

\begin{tabular}{|c|c|c|c|c|c|}
\hline \multicolumn{6}{|c|}{ Relative humidity: $60 \pm 5 \%$ Date of the finishing of research - 10.03.2015 } \\
\hline \multicolumn{6}{|c|}{ Packing - contour non-porous } \\
\hline & & Months & & & \\
\hline & & 9 & 12 & 18 & 24 \\
\hline Description & $\begin{array}{l}\text { Tablets are cream-coloured, } \\
\text { flattened cylindrical in } \\
\text { shape. }\end{array}$ & $\begin{array}{l}\text { normal in accordance } \\
\text { with PAND Tablets } \\
\text { from rhizome Acorus } \\
\text { Calamus and from } \\
\text { flower Calendula } \\
\text { officinalis }\end{array}$ & $\begin{array}{l}\text { normal in accordance } \\
\text { with PAND Tablets } \\
\text { from rhizome Acorus } \\
\text { Calamus and from } \\
\text { flower Calendula } \\
\text { officinalis }\end{array}$ & $\begin{array}{l}\text { normal in accordance } \\
\text { with PAND Tablets } \\
\text { from rhizome Acorus } \\
\text { Calamus and from } \\
\text { flower Calendula } \\
\text { officinalis }\end{array}$ & $\begin{array}{l}\text { normal in accordance } \\
\text { with PAND Tablets } \\
\text { from rhizome Acorus } \\
\text { Calamus and from } \\
\text { flower Calendula } \\
\text { officinalis }\end{array}$ \\
\hline Identification & $\begin{array}{l}\text { In the chromatogram of the } \\
\text { experimental solution the } \\
\text { time of principal peak } \\
\text { should coincide with the } \\
\text { time of camphor peak in } \\
\text { the chromatogram of } \\
\text { comparative solution. }\end{array}$ & $\begin{array}{l}\text { normal } \\
\text { in accordance with } \\
\text { PAND }\end{array}$ & $\begin{array}{l}\text { normal in accordance } \\
\text { with PAND }\end{array}$ & $\begin{array}{l}\text { normal } \\
\text { in accordance with } \\
\text { PAND }\end{array}$ & $\begin{array}{l}\text { normal } \\
\text { in accordance with } \\
\text { PAND }\end{array}$ \\
\hline Average mass & $\begin{array}{l}\text { Average mass of tablets } \\
0.580 \mathrm{~g}-0.629 \mathrm{~g} .\end{array}$ & 0.59 & 0.61 & 0.60 & 0.60 \\
\hline Disintegration, min & $\begin{array}{l}\text { Not more than fifteen } \\
\text { minutes in water (min). }\end{array}$ & 8 & 9 & 9 & 8 \\
\hline Abrasion strength & $\begin{array}{l}\text { Not more than } 1 \% \text { (in per } \\
\text { cent). }\end{array}$ & 0.7 & 0.6 & 0.5 & 0.4 \\
\hline $\begin{array}{l}\text { Firmness (in case of } \\
\text { crushin) }\end{array}$ & Not less than $3.5 \mathrm{H}$. & 4.0 & 3.8 & 3.9 & 4.1 \\
\hline Aerosil & Not more than $5.5 \%$. & 2.2 & 2.3 & 2.5 & 2.2 \\
\hline $\begin{array}{l}\text { Related impurities: 5- } \\
\text { hydroxymethylfurfural }\end{array}$ & Not more than $0.1 \%$. & 0.055 & 0.05 & 0.06 & 0.05 \\
\hline Microbiological purity & $\begin{array}{l}\text { One gramm of the drug } \\
\text { should contain not more } \\
\text { than } 10^{3} \text { bacteria, } 10^{2} \text { yeast } \\
\text { and mycelia fungi. The } \\
\text { drug shouldn't contain } \\
\text { Escherichia coli. }\end{array}$ & $\begin{array}{l}\text { normal in accordance } \\
\text { with requirements of } \\
\text { the project PAND }\end{array}$ & $\begin{array}{l}\text { normal in accordance } \\
\text { with requirements of } \\
\text { the project PAND }\end{array}$ & $\begin{array}{l}\text { normal in accordance } \\
\text { with requirements of } \\
\text { the project PAND }\end{array}$ & $\begin{array}{l}\text { normal in accordance } \\
\text { with requirements of } \\
\text { the project PAND }\end{array}$ \\
\hline Content of: - camphor & $\begin{array}{l}\text { Not less than } 0.9 \mathrm{mg} \text { in a } \\
\text { tablet. }\end{array}$ & 0.90 & 0.90 & 0.89 & 0.90 \\
\hline - $\beta$-pinen & $\begin{array}{l}\text { Not less than } 0.9 \mathrm{mg} \text { in a } \\
\text { tablet. }\end{array}$ & 0.90 & 0.91 & 0.92 & 0.92 \\
\hline
\end{tabular}


Table 3. Results of research of stability of Exkair'tablets (series 100314).

\begin{tabular}{|c|c|c|c|c|}
\hline \multicolumn{5}{|c|}{ Relative humidity: $60 \pm 5 \%$ Date of the finishing of research - 10.03.2015 } \\
\hline \multicolumn{5}{|c|}{ Packing - contour non-porous } \\
\hline & & Months & & \\
\hline & & 1 & 3 & 6 \\
\hline Description & $\begin{array}{l}\text { Tablets are cream-coloured, flattened cylindrical } \\
\text { in shape. }\end{array}$ & $\begin{array}{l}\text { normal in accordance } \\
\text { with PAND Tablets } \\
\text { from rhizome Acorus } \\
\text { Calamus and from } \\
\text { flower Calendula } \\
\text { officinalis }\end{array}$ & $\begin{array}{l}\text { normal in accordance } \\
\text { with PAND Tablets } \\
\text { from rhizome Acorus } \\
\text { Calamus and from } \\
\text { flower Calendula } \\
\text { officinalis }\end{array}$ & $\begin{array}{l}\text { normal in accordance } \\
\text { with PAND Tablets } \\
\text { from rhizome Acorus } \\
\text { Calamus and from } \\
\text { flower Calendula } \\
\text { officinalis }\end{array}$ \\
\hline Identification & $\begin{array}{l}\text { In the chromatogram of the experimental solution } \\
\text { the time of principal peak should coincide with } \\
\text { the time of camphor peak in the chromatogram of } \\
\text { comparative solution. }\end{array}$ & $\begin{array}{l}\text { normal in accordance } \\
\text { with PAND }\end{array}$ & $\begin{array}{l}\text { normal in accordance } \\
\text { with PAND }\end{array}$ & $\begin{array}{l}\text { normal in accordance } \\
\text { with PAND }\end{array}$ \\
\hline Average mass & Average mass of tablets $0.580 \mathrm{~g}-0.629 \mathrm{~g}$. & 0.60 & 0.59 & 0.59 \\
\hline Disintegration, min & Not more than fifteen minutes in water $(\mathrm{min})$. & 25 & 24 & 22 \\
\hline Abrasion strength & Not more than $1 \%$ (in per cent). & 0.4 & 0.5 & 0.4 \\
\hline $\begin{array}{l}\text { Firmness (in case of } \\
\text { crushin) }\end{array}$ & Not less than $3.5 \mathrm{H}$. & 3.8 & 3.9 & 4.1 \\
\hline Aerosil & Not more than $5.5 \%$. & 2.4 & 2.3 & 2.4 \\
\hline $\begin{array}{l}\text { Related impurities: } 5 \text { - } \\
\text { hydroxymethylfurfural }\end{array}$ & Not more than $0.1 \%$. & 0.06 & 0.06 & 0.05 \\
\hline Microbiological purity & $\begin{array}{l}\text { One gramm of the drug should contain not more } \\
\text { than } 10^{3} \text { bacteria, } 10^{2} \text { yeast and mycelia fungi. } \\
\text { The drug shouldn't contain Escherichia coli. }\end{array}$ & $\begin{array}{l}\text { normal in accordance } \\
\text { with requirements of } \\
\text { the project PAND }\end{array}$ & $\begin{array}{l}\text { normal in accordance } \\
\text { with requirements of } \\
\text { the project PAND }\end{array}$ & $\begin{array}{l}\text { normal in accordance } \\
\text { with requirements of } \\
\text { the project PAND }\end{array}$ \\
\hline $\begin{array}{l}\text { Content of: } \\
\text { - camphor }\end{array}$ & Not less than $0.9 \mathrm{mg}$ in a tablet. & 0.90 & 0.88 & 0.91 \\
\hline - $\beta$-pinen & Not less than $0.9 \mathrm{mg}$ in a tablet. & 0.91 & 0.86 & 0.86 \\
\hline
\end{tabular}

Table 3. Continue.

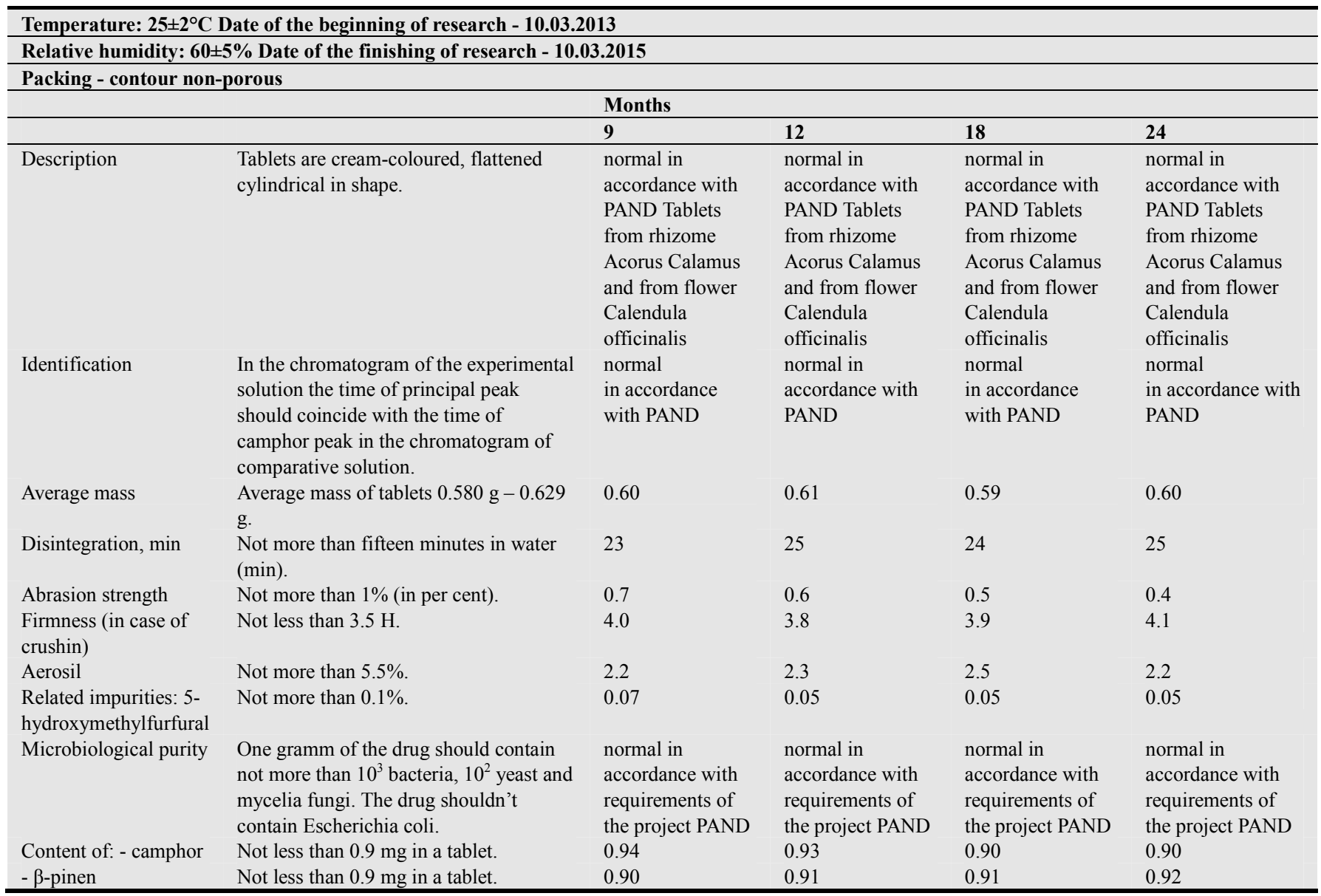


Table 4. Results of research of stability of Exkairt'ablets (series 100315).

\begin{tabular}{|c|c|c|c|c|}
\hline \multicolumn{5}{|c|}{ Relative humidity: $60 \pm 5 \%$ Date of the finishing of research - 10.03.2015 } \\
\hline \multicolumn{5}{|c|}{ Packing - contour non-porous } \\
\hline & & Months & & \\
\hline & & 1 & 3 & 6 \\
\hline Description & $\begin{array}{l}\text { Tablets are cream-coloured, flattened cylindrical } \\
\text { in shape. }\end{array}$ & $\begin{array}{l}\text { normal in accordance } \\
\text { with PAND Tablets } \\
\text { from rhizome Acorus } \\
\text { Calamus and from } \\
\text { flower Calendula } \\
\text { officinalis }\end{array}$ & $\begin{array}{l}\text { normal in accordance } \\
\text { with PAND Tablets } \\
\text { from rhizome Acorus } \\
\text { Calamus and from } \\
\text { flower Calendula } \\
\text { officinalis }\end{array}$ & $\begin{array}{l}\text { normal in accordance } \\
\text { with PAND Tablets } \\
\text { from rhizome Acorus } \\
\text { Calamus and from } \\
\text { flower Calendula } \\
\text { officinalis }\end{array}$ \\
\hline Identification & $\begin{array}{l}\text { In the chromatogram of the experimental solution } \\
\text { the time of principal peak should coincide with } \\
\text { the time of camphor peak in the chromatogram of } \\
\text { comparative solution. }\end{array}$ & $\begin{array}{l}\text { normal in accordance } \\
\text { with PAND }\end{array}$ & $\begin{array}{l}\text { normal in accordance } \\
\text { with PAND }\end{array}$ & $\begin{array}{l}\text { normal in accordance } \\
\text { with PAND }\end{array}$ \\
\hline Average mass & Average mass of tablets $0.580 \mathrm{~g}-0.629 \mathrm{~g}$. & 0.59 & 0.59 & 0.60 \\
\hline Disintegration, min & Not more than fifteen minutes in water (min). & 25 & 24 & 22 \\
\hline Abrasion strength & Not more than $1 \%$ (in per cent). & 0.4 & 0.5 & 0.4 \\
\hline $\begin{array}{l}\text { Firmness (in case of } \\
\text { crushin) }\end{array}$ & Not less than $3.5 \mathrm{H}$. & 3.8 & 3.9 & 4.1 \\
\hline Aerosil & Not more than $5.5 \%$. & 2.4 & 2.3 & 2.4 \\
\hline $\begin{array}{l}\text { Related impurities: } 5 \text { - } \\
\text { hydroxymethylfurfural }\end{array}$ & Not more than $0.1 \%$. & 0.05 & 0.06 & 0.05 \\
\hline Microbiological purity & $\begin{array}{l}\text { One gramm of the drug should contain not more } \\
\text { than } 10^{3} \text { bacteria, } 10^{2} \text { yeast and mycelia fungi. } \\
\text { The drug shouldn't contain Escherichia coli. }\end{array}$ & $\begin{array}{l}\text { normal in accordance } \\
\text { with requirements of } \\
\text { the project PAND }\end{array}$ & $\begin{array}{l}\text { normal in accordance } \\
\text { with requirements of } \\
\text { the project PAND }\end{array}$ & $\begin{array}{l}\text { normal in accordance } \\
\text { with requirements of } \\
\text { the project PAND }\end{array}$ \\
\hline $\begin{array}{l}\text { Content of: } \\
\text { - camphor }\end{array}$ & Not less than $0.9 \mathrm{mg}$ in a tablet. & 0.92 & 0.92 & 0.91 \\
\hline - $\beta$-pinen & Not less than $0.9 \mathrm{mg}$ in a tablet. & 0.91 & 0.87 & 0.86 \\
\hline
\end{tabular}

Table 4. Continue.

\begin{tabular}{|c|c|c|c|c|c|}
\hline \multicolumn{6}{|c|}{$\begin{array}{l}\text { Temperature: } 25 \pm 2^{\circ} \mathrm{C} \text { Date of the beginning of research - } 10.03 .2013 \\
\text { Relative humidity: } 60 \pm 5 \% \text { Date of the finishing of research - 10.03.2015 }\end{array}$} \\
\hline \multicolumn{6}{|c|}{ Packing - contour non-porous } \\
\hline \multicolumn{6}{|c|}{ Months } \\
\hline & & 9 & 12 & 18 & 24 \\
\hline Description & $\begin{array}{l}\text { Tablets are cream-coloured, flattened } \\
\text { cylindrical in shape. }\end{array}$ & $\begin{array}{l}\text { normal in } \\
\text { accordance with } \\
\text { PAND Tablets } \\
\text { from rhizome } \\
\text { Acorus Calamus } \\
\text { and from flower } \\
\text { Calendula } \\
\text { officinalis }\end{array}$ & $\begin{array}{l}\text { normal in } \\
\text { accordance with } \\
\text { PAND Tablets } \\
\text { from rhizome } \\
\text { Acorus Calamus } \\
\text { and from flower } \\
\text { Calendula } \\
\text { officinalis }\end{array}$ & $\begin{array}{l}\text { normal in } \\
\text { accordance with } \\
\text { PAND Tablets } \\
\text { from rhizome } \\
\text { Acorus Calamus } \\
\text { and from flower } \\
\text { Calendula } \\
\text { officinalis }\end{array}$ & $\begin{array}{l}\text { normal in } \\
\text { accordance with } \\
\text { PAND Tablets } \\
\text { from rhizome } \\
\text { Acorus Calamus } \\
\text { and from flower } \\
\text { Calendula } \\
\text { officinalis }\end{array}$ \\
\hline Identification & $\begin{array}{l}\text { In the chromatogram of the experimental } \\
\text { solution the time of principal peak should } \\
\text { coincide with the time of camphor peak in } \\
\text { the chromatogram of comparative solution. }\end{array}$ & $\begin{array}{l}\text { Normal in } \\
\text { accordance with } \\
\text { PAND }\end{array}$ & $\begin{array}{l}\text { normal in } \\
\text { accordance with } \\
\text { PAND }\end{array}$ & $\begin{array}{l}\text { Normal in } \\
\text { accordance with } \\
\text { PAND }\end{array}$ & $\begin{array}{l}\text { Normal in } \\
\text { accordance with } \\
\text { PAND }\end{array}$ \\
\hline Average mass & Average mass of tablets $0.580 \mathrm{~g}-0.629 \mathrm{~g}$. & 0.60 & 0.59 & 0.60 & 0.60 \\
\hline Disintegration, min & $\begin{array}{l}\text { Not more than fifteen minutes in water } \\
\text { (min). }\end{array}$ & 23 & 25 & 24 & 25 \\
\hline Abrasion strength & Not more than $1 \%$ (in per cent). & 0.7 & 0.6 & 0.5 & 0.4 \\
\hline $\begin{array}{l}\text { Firmness (in case of } \\
\text { crushin) }\end{array}$ & Not less than $3.5 \mathrm{H}$. & 4.0 & 3.8 & 3.9 & 4.1 \\
\hline Aerosil & Not more than $5.5 \%$. & 2.2 & 2.3 & 2.5 & 2.2 \\
\hline $\begin{array}{l}\text { Related impurities: 5- } \\
\text { hydroxymethylfurfural }\end{array}$ & Not more than $0.1 \%$. & 0.065 & 0.05 & 0.05 & 0.05 \\
\hline Microbiological purity & $\begin{array}{l}\text { One gramm of the drug should contain not } \\
\text { more than } 10^{3} \text { bacteria, } 10^{2} \text { yeast and } \\
\text { mycelia fungi. The drug shouldn't contain } \\
\text { Escherichia coli. }\end{array}$ & $\begin{array}{l}\text { normal in } \\
\text { accordance with } \\
\text { requirements of } \\
\text { the project } \\
\text { PAND }\end{array}$ & $\begin{array}{l}\text { normal in } \\
\text { accordance with } \\
\text { requirements of } \\
\text { the project } \\
\text { PAND }\end{array}$ & $\begin{array}{l}\text { normal in } \\
\text { accordance with } \\
\text { requirements of } \\
\text { the project PAND }\end{array}$ & $\begin{array}{l}\text { normal in } \\
\text { accordance with } \\
\text { requirements of } \\
\text { the project PAND }\end{array}$ \\
\hline Content of: - camphor & Not less than $0.9 \mathrm{mg}$ in a tablet. & 0.90 & 0.90 & 0.90 & 0.90 \\
\hline - $\beta$-pinen & Not less than $0.9 \mathrm{mg}$ in a tablet. & 0,91 & 0.92 & 0.91 & 0.91 \\
\hline - ascorbic acid & From 0.045 to $0.055 \mathrm{~g}$ in a tablet. & 0.0493 & 0.0492 & 0.0493 & 0.0492 \\
\hline
\end{tabular}




\section{Conclusions}

1. The specification of test of stability of the tablets "Exkair" by method of long-term storage in the natural mode is developed: storage temperature $-25 \pm 2{ }^{\circ} \mathrm{C}$, relative humidity of definition - $(60 \pm 5) \%$.

2. The assessment of quality of the tablets "Exkair" on all indicators of quality is carried out: the description, identification, average weight, deviations from average mass, uniformity of dispensing, durability on attrition, disintegration, aerosil, related impurity, microbiological purity, quantitative definition, period of storage with the description of techniques of their definition, regulated by the draft of AND on tablets.

3. According to requirements of test of stability of tablets numerical values of indicators of quality with the appendix of techniques of their definition are defined.

4. An established period of the validity of the tablets "Exkair" which makes 24 months.

\section{References}

[1] CPMP / ICH /2736/ 99 corr (Q1A R) Stability testing guidelines: stability testing of new drug substances and products. Note for guidance on stability testing: stability testing of new drag substances and products (revision), 2000.

[2] The harmonized guidelines of ICH Q1A "Studying of Stability of New Medicines"

[3] The resolution of the government of the Republic of Kazakhstan of December 5, 2011 No. 1459 "About the approval of Rules of production and quality control, and also carrying out tests of stability and establishment of period of storage and repeated control of medicines, products of medical appointment and medical equipment".

[4] Meshkovsky A. P. Appropriate practice of storage of medicines / A. P. Meshkovsky // Farmateka. 2000. - No. 3. P. 27-30.

[5] Meshkovsky A. P. Tests of stability and establishment of expiration dates of medicines // Farmateka 2000. No. 2. P. 2538.

[6] Management 42-3.4: 2004 Quality manuals. Medicines. Production of finished pharmaceutical products. - Kiev, Ministry of Health of Ukraine, 2004.

[7] Management Ministry of Health of Ukraine 42-3.3:2004 "Quality manual. Medicines. Stability studying".

[8] Management Ministry of Health of Ukraine 42-3.4:2004 "Quality manuals. Medicines. Production of finished pharmaceutical products".

[9] Tulegenova A. U. The concept of efficiency and safety of medicines, the State Pharmacopoeia of the Republic of Kazakhstan // Pharmacy Kazakhstan. - 2007. - P. 12-14.

[10] Tulegenova A. U. Some aspects of the stability testing of medicines (message) // Pharmacy Kazakhstan. - 2006. - №3. P. 29-31.

[11] Tulegenova A. U. Some aspects of the stability testing of medicines (message) // Pharmacy Kazakhstan. - 2006. - №4. P. 38-40.

[12] Tulegenova A. U. Some aspects of the stability testing of medicines (message) // Pharmacy Kazakhstan. - 2006. - №5. P. 31-34.

[13] Brian R. Mallhews. Regulatory Aspects of stability testing in Europe // Drug Develop and Industrial Pharmacy. - 1999. Vol. 27(7). - P. 831-856.

[14] The draft of Provisional Analytical Normative Document of the Republic of Kazakhstan (PAND) «Tablets from rhizome Acorus Calamus and from flower Calendula officinalis».

[15] State Pharmacopoeia of Republic of Kazakhstan, Vol. I, "Tablets" Monograph. 